\title{
Periphyton-based cage culture of Nile tilapia: An interesting model for small-scale farming
}

\author{
F. Garcia ${ }^{\mathrm{a}, *}$, O.J. Sabbag ${ }^{\mathrm{b}}$, J.M. Kimpara ${ }^{\mathrm{c}}$, D.M. Romera ${ }^{\mathrm{d}}$, N.S. Sousa ${ }^{\mathrm{a}}$, E.M. Onaka ${ }^{\mathrm{a}}$, I.P. Ramos \\ a Instituto de Pesca, APTA/SAA, Rodovia Washington Luiz (SP 310) km 445, Postal Box 1052, 15025-970 São José do Rio Preto, SP, Brazil \\ ' FEIS - Universidade Estadual Paulista 'Julio de Mesquisata Filho' - UNESP, Avenida Brasil, 56 - Centro, 15385-000 Ilha Solteira, SP, Brazil \\ c Brazilian Agricultural Research Corporation, Embrapa Mid-North, BR 343, km 35, Zona Rural, 64200-970 Parnaíba, PI, Brazil \\ d Instituto Agronômico de Campinas, APTA/SAA, Postal Box 61, 15500-970 Votuporanga, SP, Brazil
}

\section{A R T I C L E I N F O}

\section{Keywords:}

Profitability

Production cost

Economics

Oreochromis niloticus

\begin{abstract}
A B S T R A C T
We evaluated the production costs and the profitability of using bamboo substrates to enhance periphyton production in cages, in combination with a restricted diet and reduced stocking densities. Nile tilapia $(46.56 \pm 2.53 \mathrm{~g})$ were placed in 21 cages, and the inclusion of bamboo substrates was evaluated in three different stocking densities $\left(40,60\right.$, and $80 \mathrm{~kg}$ of fish $\left./ \mathrm{m}^{3}\right)$ in association with two feeding schemes $(100 \%$ and $50 \%$ of daily ration). No bamboo substrates were included in the control group. The inclusion of the bamboo substrates in cages increased fish weight gain, shortened the farming cycle length, and improved the feed conversion ratio. The proposed production model of Nile tilapia farming in cages with substrates offers a way for small-scale producers to increase the efficiency of the system with annual operating income up to $57 \%$ higher and the profitability index up to $87 \%$ higher than the currently used system adopted by Brazilian farmers.
\end{abstract}

\section{Introduction}

Most aquaculture products worldwide are produced by small and medium-scale facilities that are owned or rented by the producers, especially in Asia, where $94 \%$ of world's population was devoted to aquaculture (FAO, 2016).

Similarly in Brazil, family-based aquaculture significantly contributes to the total volume of fish production. For this reason, the federal government has been developing policy focused on family farmers. Among these actions, the aquaculture planning on public waters was conducted by assigning areas in inland and marine aquaculture parks to fish farmers. The aquaculture areas inside parks are classified as onerous or non-onerous. The owners or renters of nononerous areas meet criteria such as living in the nearest municipality, having low income, receiving assistance from social program, or participating in professional fishing activities, among others.

Within continental aquaculture parks, the most common form of aquaculture is the production of Nile tilapia in net-cages. The system is classified as intensive and uses stocking densities ranging from 80 to $120 \mathrm{~kg} / \mathrm{m}^{3}$ (Garcia et al., 2013; Ayroza et al., 2014). This system is commonly used in large-scale production, in which the production volume compensates for the low profit margin.

In order to make the production of Nile tilapia in cages more attractive to small-scale producers, the efficiency of the current production model must improve. A previous study showed that reducing the stocking density in this production system not only improved fish health and water quality but also reduced the feed conversion ratio. This resulted in lower production costs, and a higher operating income (Garcia et al., 2013).

Another way of improving the efficiency of the tilapia production system is to reduce the expense of feeding, which represents the highest input cost (Garcia et al., 2013; Ayroza et al., 2014) and energy expenditure (Garcia et al., 2014). Tilapia show opportunistic omnivore feeding behaviour, with a great tendency towards herbivory (Beveridge and Baird, 2000), and have morphological adaptations that allow them to feed on phytoplankton and periphyton (Sanderson et al., 1996). Therefore, if natural food is present, the amount of commercial diet can be reduced.

Studies in ponds showed that it was beneficial to include substrates on which periphyton (a mixture of algae, cyanobacteria, heterotrophic microbes, and detritus that attaches to submerged aquatic surfaces) could grow, as it provides a good source of quality feed for fish (Keshavanath et al., 2004; Saikia and Das, 2009). Previous studies were not able to demonstrate whether it was economically viable to include substrates for periphyton production in cages (Norberg, 1999; Huchette and Beveridge, 2003). However, recent publication of Sakr et al. (2015)

\footnotetext{
* Corresponding author at: Instituto de Pesca, APTA/SAA, Rodovia Washington Luiz (SP 310) km 445, Postal Box 1052, 15025-970 São José do Rio Preto, SP, Brazil.

E-mail address: fgarcia@apta.sp.gov.br (F. Garcia).
} 
demonstrated that for juvenile of Nile tilapia (mean weight 2-25 g), the most cost-effective feeding strategy was offer to fish a diet contained $15 \%$ crude protein that included periphyton in relation to a diet containing $25 \%$ crude protein but no periphyton.

In Brazil, we showed that the inclusion of bamboo substrates inside net-cages in hydroelectric reservoirs allows producing up to $52 \mathrm{~kg} / \mathrm{m} 3$ of Nile tilapia using $32 \%$ less diet in a period almost $20 \%$ shorter than in the net-cage with no substrate (Garcia et al., 2016). Thus, the objective of the present paper is to evaluate if this production model of Nile tilapia in net-cages with substrates would enable small-scale producers to increase their income.

\section{Materials and methods}

The economic analysis of the inclusion of bamboo substrates in cages to produce Nile tilapia Oreochromis niloticus $(46.56 \pm 2.53 \mathrm{~g}$ ) under three stocking densities and two feeding regimes was evaluated. To determine the best production option for small-scale farmers, the cost of production was calculated per cage and per $\mathrm{kg}$ fish produced, considering two possible slaughter weights: $500 \mathrm{~g}$ (which is possible market sizes for tilapia in Brazil) and $800 \mathrm{~g}$ (the currently size for tilapia sale). Farmers can use these results to scale the number of cages that they require to obtain a desired income.

To obtain this data, growth performance was evaluated when fish reached $500 \mathrm{~g}$. Thus, the experiment goes on and fish were evaluated again when they reached $800 \mathrm{~g}$. For fish with $500 \mathrm{~g}$, the three final biomass were 25,37 and $50 \mathrm{~kg} / \mathrm{m} 3$ and for fish with $800 \mathrm{~g}$ of final weight, the evaluated biomass were 40,60 and $80 \mathrm{~kg} / \mathrm{m} 3$. For each stocking density two feeding schemes were evaluated: two meals a day $-100 \%$ of daily ration and one meal a day $-50 \%$ of daily ration, with three replicates per treatment. The control group (CTRL) comprised three cages without bamboo substrates, in which fish were stocked at a final density of $80 \mathrm{~kg} / \mathrm{m}^{3}$ and fed two meals a day - $100 \%$ of daily ration, following the management used by Brazilian fish farmers. The experiment details are described in Garcia et al. (2016).

To the economic analysis, growth performance means of each treatment obtained in Garcia et al. (2016) were used. The profitability study considered only the 800-g slaughter weight, because in Brazil, 500-g fish are sold in specific markets and their price vary widely among regions.

To calculate the farming operation cost, we used the structure adopted by the Agricultural Economics Institute (IEA), based on the total operating cost (TOC) proposed by Matsunaga et al. (1976). The effective operating costs (EOC) are the labour expenses and the material consumed. The TOC includes the EOC and other expenses that are calculated as $5 \%$ of the EOC, using an interest rate of $5.5 \%$ per year on $50 \%$ of the EOC. Depreciation was calculated using the straight-line method, proportional to the area of farming in relation to the set of elements that corresponds to the fixed capital of the activity associated with the service life of each good. The economic evaluation period was related to the farming cycle, with prices in 2017 US dollar.

The study used the profitability analysis indicators proposed by Martin et al. (1998), which are defined as follows:

Gross Revenue (GR): constituted by the revenue expected in return for a given amount of production for each treatment, with a predefined or effectively received sales price, expressed by $\mathrm{GR}=\mathrm{Ap} \times \mathrm{Up}$, in which $\mathrm{Ap}=$ the production by area unit and $\mathrm{Up}=$ unit price of the product (US\$).

Operating Income (OI): results from the difference between the gross income and the operating expenses. The indicator that results from this index measures the short-term profitability of the activity, considering the financial and operational conditions of the activity through the use of the expression OI $=$ GR - TOC.

Profitability Index (PI): shows the relationship between the operating income and the gross revenue in percentage. It is an important measurement of the profitability in agribusiness because it shows the available income rate after all operating costs are paid. It is expressed as $\mathrm{PI}=(\mathrm{OI} / \mathrm{GR}) \times 100$.

Break-Even Point (BEP): indicates the cost related to the product unit. In other words, it determines the minimum production that is necessary to cover the cost of production given the sales price of a unit. The formula used is BEP $=$ TOC / Up.

Considering that the feed represents around $70 \%$ of the production costs, we explored the concept of risk by assuming a $25 \%$ increase in the price of feed, then verifying which treatment would be the most resilient to this condition.

Bamboo was used to manufacture the substrates for insertion because it is readily available in rural areas. We calculated the time spent harvesting the stalks, assembling the modules, and installing them on the net tanks, as well as the time spent on maintenance of the modules at the end of each farming cycle. The total number of hours required for each activity was calculated by multiplying the number of hours of each activity by the minimum number of workers that the activity demanded and by the number of days on which it is executed. We assumed that the modules would be replaced every two farming cycles, because they often suffered damage during harvesting and tended to accumulate golden mussels Limnoperna fortunei (an invasive bivalve of Asian origin).

\section{Results}

The total time spent on each fish farm labour activity varied according to the treatment (Table 1 ). The daily activities that required the highest amount of labour were: feeding, removal of dead fish, and fish weight sampling. For cages maintained at the same stocking density, the treatments that were fed once and twice a day required a similar amount of total labour (Table 1), because the fish that were fed once a day needed more time to reach slaughter weight.

Considering that 500-g whole fish are sold in specific markets with different sale prices, we decided do not include them in the profitability analysis and limited the evaluation of this product to the production costs (Table 2 and Fig. 1). However, it is important to determine the production costs of these fish because rearing them only to this weight allows a higher number of farming cycles per year, which provides the possibility of increasing the profitability index.

The mean daily weight gain of the fish reared to $500 \mathrm{~g}$ was $2.95 \pm 0.67 \mathrm{~g} /$ fish/day and fish reared to $800 \mathrm{~g}, 3.29 \pm 0.49 \mathrm{~g} / \mathrm{fish} /$ day. Although the production costs per cage were lower for the $500 \mathrm{~g}$ fish than the $800 \mathrm{~g}$ fish, the production costs per kilogram of fish were higher (Table 2), due to the higher investment in fixed capital and because the costs were insufficiently offset by the higher fish weight.

Considering production up to a weight of $500 \mathrm{~g}$, the highest stocking density treatment that provided $100 \%$ of daily ration plus substrates provided the best outcome, with a higher mean daily weight gain, lower feed conversion ratio, lower production cost per $\mathrm{kg}$ of fish produced, and higher number of farming cycles per year. When fish reached $800 \mathrm{~g}$, the performance and economical results of this treatment were inferior to those of other treatments with higher stocking density, indicating that there was a limit on the cage's support capacity (Garcia et al., 2016) (Table 2).

At the end of the experiment, the cages with the highest stocking density produced higher gross revenue than the cages with lower densities. However, the intensification of production increased the production cost, raising the break-even point. The stocking density of $40 \mathrm{~kg} / \mathrm{m}^{3}$ was less viable economically, as it was associated with lower productivity, operating income, and profitability index (Table 2).

The treatments that provided greater advantage for fish reared to a slaughter weight of $800 \mathrm{~g}$, producing a higher operating income and higher profitability index, were those with substrate at the highest stocking density fed $50 \%$ of daily ration followed by density of $60 \mathrm{~kg}$ / 
Table 1

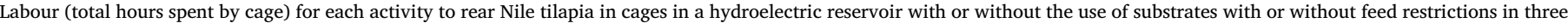
different stocking densities.

\begin{tabular}{|c|c|c|c|c|c|c|c|c|}
\hline & \multicolumn{7}{|c|}{ Hours per cage } & \multirow{3}{*}{ Fish weight } \\
\hline & \multicolumn{6}{|c|}{ With bamboo substrates for periphyton } & \multirow{2}{*}{$\frac{\text { No bamboo substrates }}{100 \% \text { ration }}$} & \\
\hline & $50 \%$ ration & $100 \%$ ration & $50 \%$ ration & $100 \%$ ration & $50 \%$ ration & $100 \%$ ration & & \\
\hline & $25 \mathrm{~kg} / \mathrm{m}^{3}$ & & $37 \mathrm{~kg} / \mathrm{m}^{3}$ & & $50 \mathrm{~kg} / \mathrm{m}^{3}$ & & & \\
\hline Manufacture of substrates & 2.0 & 1.3 & 2.0 & 1.3 & 2.0 & 1.3 & - & $500 \mathrm{~g}$ \\
\hline Installation of substrates inside the cages & 2.7 & 2.7 & 2.7 & 2.7 & 2.7 & 3.6 & - & \\
\hline Initial stocking of fish & 2.3 & 2.3 & 2.9 & 2.9 & 3.4 & 3.4 & 3.4 & \\
\hline Feeding and removal of dead fish & 4.5 & 5.8 & 4.5 & 6.0 & 4.5 & 6.0 & 8.6 & \\
\hline Fish weighting for feed adjustment & 4.8 & 3.1 & 4.8 & 3.2 & 4.8 & 3.2 & 4.6 & \\
\hline Harvest of fish & 2.3 & 2.3 & 3.4 & 3.4 & 4.6 & 4.6 & 4.6 & \\
\hline Cleaning and conservation of cages and substrates & 1.1 & 1.1 & 1.1 & 1.1 & 1.1 & 1.1 & 1.1 & \\
\hline \multirow[t]{5}{*}{ Total } & 19.7 & 18.5 & 21.4 & 20.5 & 23.1 & 23.1 & 22.3 & \\
\hline & \multicolumn{7}{|c|}{ Hours per cage } & Fish weight \\
\hline & \multicolumn{6}{|c|}{ With bamboo substrates for periphyton } & No bamboo substrates & \\
\hline & $50 \%$ ration & $100 \%$ ration & $50 \%$ ration & $100 \%$ ration & $50 \%$ ration & $100 \%$ ration & $100 \%$ ration & \\
\hline & $40 \mathrm{~kg} / \mathrm{m}^{3}$ & & $60 \mathrm{~kg} / \mathrm{m}^{3}$ & & $80 \mathrm{~kg} / \mathrm{m}^{3}$ & & & \\
\hline Manufacture of substrates & 2.6 & 1.9 & 2.7 & 2.0 & 2.5 & 2.2 & - & $800 \mathrm{~g}$ \\
\hline Installation of substrates inside the cages & 2.7 & 2.7 & 2.7 & 2.7 & 2.7 & 3.6 & - & \\
\hline Initial stocking of fish & 2.3 & 2.3 & 2.9 & 2.9 & 3.4 & 3.4 & 3.4 & \\
\hline Feeding and removal of dead fish & 6.0 & 8.7 & 6.2 & 9.0 & 5.8 & 10.3 & 9.7 & \\
\hline Fish weighting for feed adjustment & 6.4 & 4.6 & 6.6 & 4.8 & 6.2 & 5.5 & 5.2 & \\
\hline Harvest of fish & 2.3 & 2.3 & 3.4 & 3.4 & 4.6 & 4.6 & 4.6 & \\
\hline Cleaning and conservation of cages and substrates & 1.1 & 1.1 & 1.1 & 1.1 & 1.1 & 1.1 & 1.1 & \\
\hline Total & 23.4 & 23.6 & 25.5 & 25.9 & 26.4 & 30.8 & 24.0 & \\
\hline
\end{tabular}

Table 2

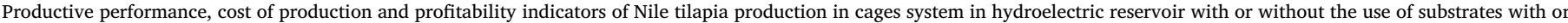
without feed restriction in three different stocking densities.

\begin{tabular}{|c|c|c|c|c|c|c|c|c|}
\hline & \multicolumn{6}{|c|}{ With bamboo substrates for periphyton } & \multirow{2}{*}{$\begin{array}{l}\text { No bamboo substrates } \\
100 \% \text { ration }\end{array}$} & \multirow[t]{3}{*}{ Fish weight } \\
\hline & $50 \%$ ration & $100 \%$ ration & $50 \%$ ration & $100 \%$ ration & $50 \%$ ration & $100 \%$ ration & & \\
\hline & \multicolumn{2}{|l|}{$25 \mathrm{~kg} / \mathrm{m}^{3}$} & \multicolumn{2}{|l|}{$37 \mathrm{~kg} / \mathrm{m}^{3}$} & \multicolumn{2}{|l|}{$50 \mathrm{~kg} / \mathrm{m}^{3}$} & & \\
\hline Total production per cage $(\mathrm{kg})$ & 150.00 & 150.00 & 222.00 & 222.00 & 300.00 & 300.00 & 300.00 & $500 \mathrm{~g}$ \\
\hline Daily weight gain (g/fish/day) & 2.39 & 3.74 & $2.39 \pm 0.02$ & 3.64 & $2.40 \pm 0.01$ & 3.61 & 2.50 & \\
\hline Feed conversion ratio & 1.09 & 1.05 & $1.07 \pm 0.07$ & 1.22 & $1.27 \pm 0.00$ & 1.08 & 1.60 & \\
\hline Total operating cost (US\$/cage) & 228.00 & 211.50 & 295.26 & 295.26 & 390.00 & 348.00 & 411.00 & \\
\hline Total operating cost (US\$/kg) & 1.52 & 1.41 & 1.33 & 1.33 & 1.30 & 1.16 & 1.37 & \\
\hline \multirow[t]{4}{*}{ Farming cycle per year (days) } & 1.92 & 3.02 & 1.92 & 2.92 & 1.92 & 2.92 & 2.03 & \\
\hline & \multicolumn{6}{|c|}{ With bamboo substrates for periphyton } & No bamboo substrates & Fish weight \\
\hline & $50 \%$ ration & $100 \%$ ration & $50 \%$ ration & $100 \%$ ration & $50 \%$ ration & $100 \%$ ration & $100 \%$ ration & \\
\hline & \multicolumn{2}{|l|}{$40 \mathrm{~kg} / \mathrm{m}^{3}$} & \multicolumn{2}{|l|}{$60 \mathrm{~kg} / \mathrm{m}^{3}$} & \multicolumn{2}{|l|}{$80 \mathrm{~kg} / \mathrm{m}^{3}$} & & \\
\hline Total production per cage $(\mathrm{kg})$ & 214.54 & 209.45 & 323.03 & 343.87 & 417.84 & 372.38 & 411.79 & $800 \mathrm{~g}$ \\
\hline Daily weight gain (g/fish/day) & 3.07 & 3.91 & 2.68 & 3.53 & 2.66 & 3.62 & 3.56 & \\
\hline Feed conversion ratio & 1.06 & 1.59 & 1.22 & 1.61 & 1.29 & 1.79 & 1.84 & \\
\hline Gross revenue (US\$/cage) & 330.06 & 322.23 & 496.97 & 529.03 & 642.83 & 572.90 & 633.53 & \\
\hline Total operating cost (US\$/cage) & 279.98 & 306.76 & 373.06 & 418.76 & 444.70 & 537.53 & 528.95 & \\
\hline Total operating cost (US\$/kg) & 1.31 & 1.46 & 1.15 & 1.22 & 1.06 & 1.44 & 1.28 & \\
\hline Operating income (US\$/cage) & 50.08 & 15.47 & 123.91 & 110.27 & 198.13 & 35.37 & 104.58 & \\
\hline Profitability index (\%) & 15.17 & 4.80 & 24.93 & 20.84 & 30.82 & 6.17 & 16.51 & \\
\hline Break-even point $(\mathrm{kg})$ & 181.81 & 199.19 & 242.25 & 271.92 & 288.77 & 349.05 & 343.47 & \\
\hline Farming cycle per year (days) & 1.45 & 2.01 & 1.41 & 1.93 & 1.49 & 1.68 & 1.80 & \\
\hline Operating income (US\$/year) & 72.53 & 31.02 & 174.62 & 212.96 & 295.17 & 59.49 & 188.03 & \\
\hline
\end{tabular}

Sale price of fish $(800 \mathrm{~g})=\mathrm{US} \$ 1.54 / \mathrm{kg}$.

US\$1.00 = R\$3.25 (May 2017). 


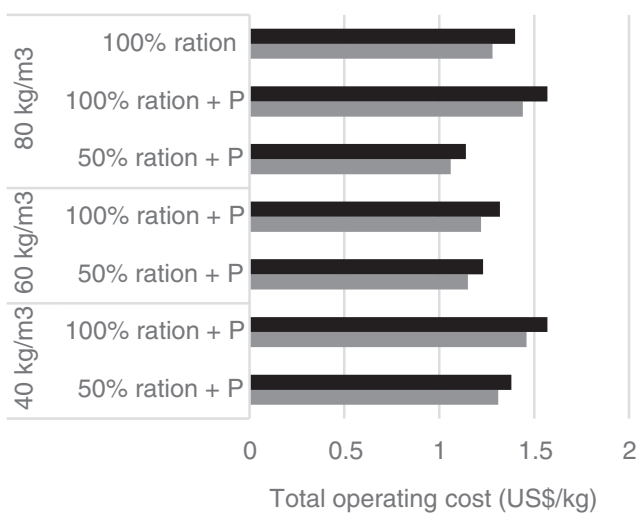

- increase on the feed price current feed price

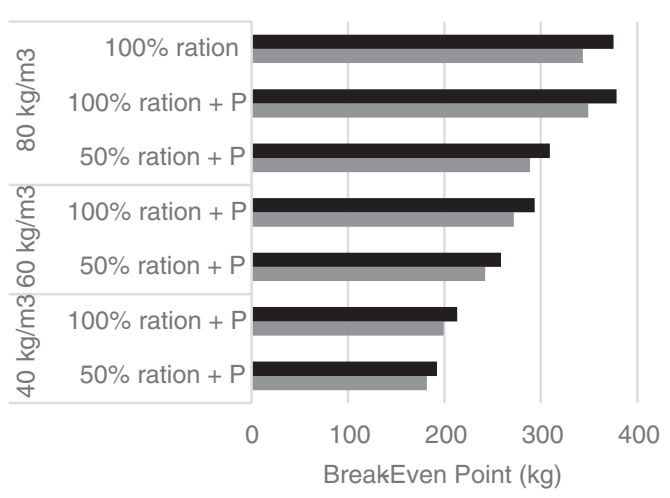

- increase on the feed price current feed price

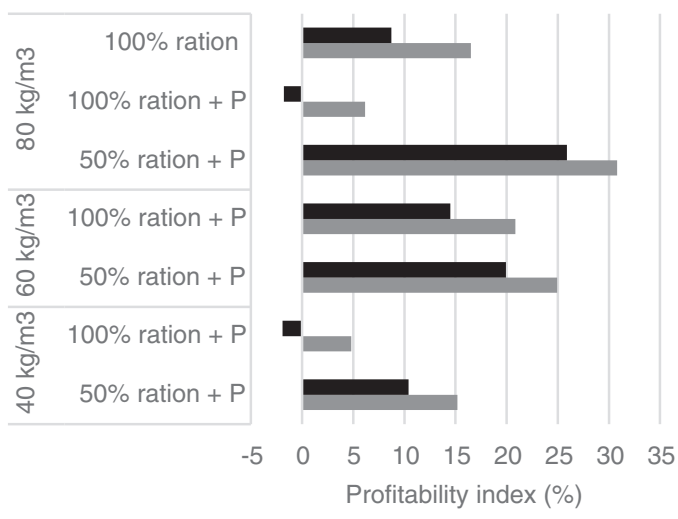

increase on the feed price current feed price

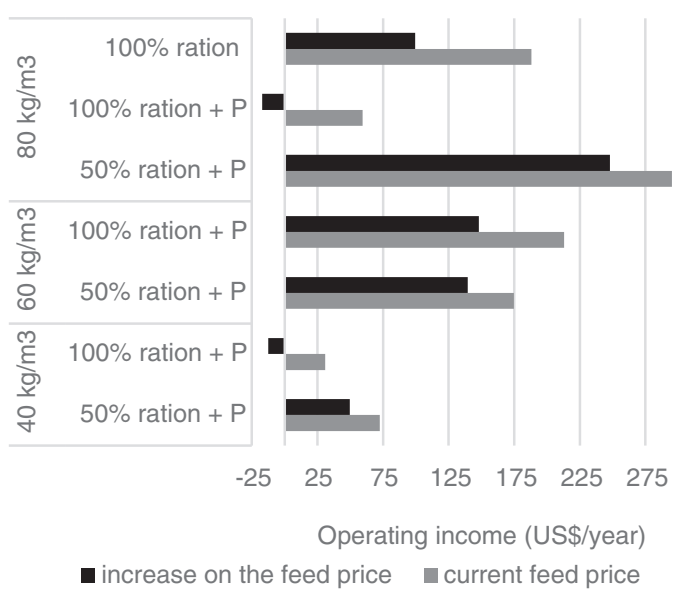

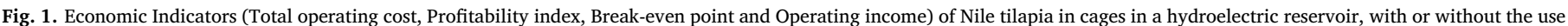
of substrates, with or without feed restrictions, in three different stocking densities. Abbreviation $\mathrm{P}$ in the legend corresponds to periphyton.

m3 fed $100 \%$ and $50 \%$ of daily ration, respectively (Table 2 ).

In the CTRL commercial diet supplies represented approximately $70 \%$ of the production costs for both slaughter weights (500 and $800 \mathrm{~g}$ ). Including substrate reduced the percentage of feed supply on the production cost, and reducing the stocking density there was a lower participation of this item in relation to the labour cost. Feeding the fish two daily meals $100 \%$ of ration caused the cost of supplies to be the highest proportion of the total costs, compared with fish fed once a day with $50 \%$ of daily ration (Table 3 ).

The simulated $25 \%$ increase in feed costs highlighted the importance of reducing feed costs, which already represented approximately $70 \%$ of the total production cost. The treatments with substrate improved the resilience of the system. The group with higher operating income, higher profitability index and that was most cost-effective under the simulated scenario was the same classified in the real situation: with substrate at the highest stocking density fed $50 \%$ of daily ration followed by density of $60 \mathrm{~kg} / \mathrm{m} 3$ fed $100 \%$ and $50 \%$ of daily ration. Meanwhile, most of the treatments that received $100 \%$ of daily ration under this scenario of increased feed costs were not profitable (Table 4).

\section{Discussion}

This study explored the cost-effectiveness of the production of Nile tilapia in net-cages in hydroelectric reservoirs using substrates to promote the production of periphyton that supplement the fish diet. This production model may be appealing to small-scale producers because it was more efficient and profitable than traditional tilapia farming in cages, allowing the farmers to obtain income using small production modules and family labour.

Inserting bamboo substrates in the cages to promote periphyton growth increased the weight gain of the fish, shortened the farming cycle, and reduced the feed conversion ratio up to $52 \mathrm{~kg} / \mathrm{m} 3$ (Garcia et al., 2016), allowing Nile tilapia to be produced with less use of commercial extruded feed and, therefore, lower production cost.

The feed conversion ratio of the fish that received $50 \%$ of daily ration was lower than that of the fish that fed $100 \%$ of daily ration, particularly for the last phase of cultivation (fish with $800 \mathrm{~g}$ ). Even though the fish whose feed was restricted needed, on average, 30\% more time to reach slaughter weight, they were associated with profitability increases of 3.16 (at a stocking density of $40 \mathrm{~kg} / \mathrm{m}^{3}$ ), 1.2 (stocking density $60 \mathrm{~kg} / \mathrm{m}^{3}$ ), and 5 times (stocking density $80 \mathrm{~kg} / \mathrm{m}^{3}$ ) that of the group that received $100 \%$ of daily ration. This result is due to the fact that in this production system, the commercial diet composes $70 \%$ of the production cost (Table 3) (Ayroza et al., 2014). The higher proportion of production costs associated with feed is typical of intensive tilapia production systems (Piumsombun et al., 2005; Ofori et al., 2010), and the dependence on extruded feed shows the degree to which the competitiveness of fish farmers is affected by changes in the feed price and by the quality of feed offered.

The simulation of a $25 \%$ increase in the feed price demonstrated the higher resilience of productive models that do not rely as heavily on feed (with substrate and fed $50 \%$ of daily ration). The insertion of substrate in the cages is a valuable option for small-scale fish farmers that allows them to reduce their dependency on commercial feed.

In the control treatment, feed supplies represented around $70 \%$ of the production cost for both sizes evaluated (500 $\mathrm{g}$ and $800 \mathrm{~g}$ ). The inclusion of substrate reduced the proportion of the production cost 
Table 3

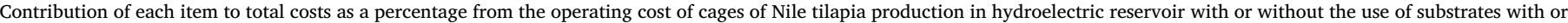
without feed restriction in three different stocking densities.

\begin{tabular}{|c|c|c|c|c|c|c|c|c|}
\hline & \multicolumn{6}{|c|}{ With bamboo substrates for periphyton } & \multirow{2}{*}{$\frac{\text { No bamboo substrates }}{100 \% \text { ration }}$} & \multirow[t]{3}{*}{ Fish weight } \\
\hline & $50 \%$ ration & $100 \%$ ration & $50 \%$ ration & $100 \%$ ration & $50 \%$ ration & $100 \%$ ration & & \\
\hline & $25 \mathrm{~kg} / \mathrm{m}^{3}$ & & $37 \mathrm{~kg} / \mathrm{m}^{3}$ & & $50 \mathrm{~kg} / \mathrm{m}^{3}$ & & & \\
\hline Labour & 42.84 & 41.48 & 36.77 & 34.03 & 30.97 & 31.63 & 24.49 & $500 \mathrm{~g}$ \\
\hline Inputs & 45.43 & 48.86 & 52.96 & 57.60 & 60.10 & 60.56 & 67.01 & \\
\hline Maintenance & 4.35 & 4.52 & 4.49 & 4.58 & 4.55 & 4.61 & 4.58 & \\
\hline Depreciation & 7.38 & 5.14 & 5.78 & 3.79 & 4.38 & 3.20 & 3.92 & \\
\hline
\end{tabular}

\begin{tabular}{|c|c|c|c|c|c|c|c|c|}
\hline & \multicolumn{6}{|c|}{ With bamboo substrates for periphyton } & \multirow{2}{*}{$\begin{array}{l}\text { No bamboo substrates } \\
100 \% \text { ration }\end{array}$} & \multirow[t]{3}{*}{ Fish weight } \\
\hline & $50 \%$ ration & $100 \%$ ration & $50 \%$ ration & $100 \%$ ration & $50 \%$ ration & $100 \%$ ration & & \\
\hline & $40 \mathrm{~kg} / \mathrm{m}^{3}$ & & $60 \mathrm{~kg} / \mathrm{m}^{3}$ & & $80 \mathrm{~kg} / \mathrm{m}^{3}$ & & & \\
\hline Labour & 39.28 & 34.06 & 33.13 & 28.30 & 29.79 & 25.31 & 20.00 & $800 \mathrm{~g}$ \\
\hline Inputs & 48.28 & 56.13 & 56.19 & 63.09 & 60.75 & 66.47 & 71.96 & \\
\hline Maintenance & 4.38 & 4.51 & 4.47 & 4.57 & 4.53 & 4.59 & 4.60 & \\
\hline Depreciation & 8.06 & 5.30 & 6.21 & 4.04 & 4.93 & 3.63 & 3.44 & \\
\hline
\end{tabular}

devoted to feed for all the treatments. Lower stocking densities as well as feed restriction ( $50 \%$ of the daily recommended feed) were associated with lower feed cost in relation to the labour costs. Considering that the model is designed for use by small-scale producers, it is important to consider that offering one meal per day (containing 50\% of daily ration) has many benefits. In addition to reducing the production costs, increasing profitability and reducing dependence on external supplies, it allow farmers to be available during the day to perform different agricultural activities that diversify their production. On family-owned properties, fish farming generally represents only one of several activities performed by the owners. This diversification builds in resilience to a family's economic prospects, particularly if climatic events or market conditions that impact one activity do not affect each other (Setboonsarng and Edwards, 1998). Integrating cage farm into other daily and seasonal tasks is important, especially for small producers. The time needed to manage the aquaculture activities should not represent an obstacle or prevent other daily management tasks from being carried out on a rural property (Lebel et al., 2009).

A recent study of a fish farmers group of Nile tilapia in net-cage in hydroelectric reservoirs in the State of São Paulo, Brazil, demonstrated

Table 4

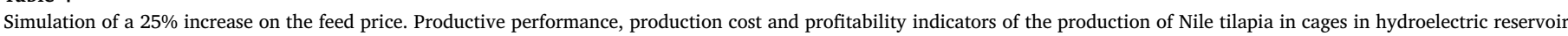
with or without the use of substrates with or without feed restriction in three different stocking densities.

\begin{tabular}{|c|c|c|c|c|c|c|c|c|}
\hline & \multicolumn{6}{|c|}{ With bamboo substrates for periphyton } & \multirow{2}{*}{$\begin{array}{l}\text { No bamboo substrates } \\
100 \% \text { ration }\end{array}$} & \multirow[t]{2}{*}{ Fish weight } \\
\hline & $50 \%$ ration & $100 \%$ ration & $50 \%$ ration & $100 \%$ ration & $50 \%$ ration & $100 \%$ ration & & \\
\hline & $25 \mathrm{~kg} / \mathrm{m}^{3}$ & & $37 \mathrm{~kg} / \mathrm{m}^{3}$ & & $50 \mathrm{~kg} / \mathrm{m}^{3}$ & & & \\
\hline Total production per cage $(\mathrm{kg})$ & 150.00 & 150.00 & 222.00 & 222.00 & 300.00 & 300.00 & 300.00 & $500 \mathrm{~g}$ \\
\hline Daily weight gain (g/fish/day) & 2.39 & 3.74 & 2.39 & 3.64 & 2.40 & 3.61 & 2.50 & \\
\hline Feed conversion ratio & 1.09 & 1.05 & 1.07 & 1.22 & 1.27 & 1.08 & 1.60 & \\
\hline Total operating cost (US\$/cage) & 238.50 & 222.00 & 310.80 & 315.24 & 414.00 & 372.00 & 444.00 & \\
\hline Total operating cost (US $\$ / \mathrm{kg}$ ) & 1.59 & 1.48 & 1.40 & 1.42 & 1.38 & 1.24 & 1.48 & \\
\hline \multirow[t]{4}{*}{ Productive cycle (days) } & 1.92 & 3.02 & 1.92 & 2.92 & 1.92 & 2.92 & 2.03 & \\
\hline & \multicolumn{6}{|c|}{ With bamboo substrates for periphyton } & No bamboo substrates & Fish weight \\
\hline & $50 \%$ ration & $100 \%$ ration & $50 \%$ ration & $100 \%$ ration & $50 \%$ ration & $100 \%$ ration & $100 \%$ ration & \\
\hline & $40 \mathrm{~kg} / \mathrm{m}^{3}$ & & $60 \mathrm{~kg} / \mathrm{m}^{3}$ & & $80 \mathrm{~kg} / \mathrm{m}^{3}$ & & & \\
\hline Total production per cage $(\mathrm{kg})$ & 214.54 & 209.45 & 323.03 & 343.87 & 417.84 & 372.38 & 411.79 & $800 \mathrm{~g}$ \\
\hline Daily weight gain (g/fish/day) & 3.07 & 3.91 & 2.68 & 3.53 & 2.66 & 3.62 & 3.56 & \\
\hline Feed conversion ratio & 1.06 & 1.59 & 1.22 & 1.61 & 1.29 & 1.79 & 1.84 & \\
\hline Gross revenue (US\$/cage) & 330.06 & 322.23 & 496.97 & 529.03 & 642.83 & 572.90 & 633.53 & \\
\hline Total operating cost (US\$/cage) & 295.74 & 328.40 & 397.96 & 452.32 & 476.42 & 583.07 & 578.22 & \\
\hline Total operating cost (US\$/kg) & 1.38 & 1.57 & 1.23 & 1.32 & 1.14 & 1.57 & 1.40 & \\
\hline Operating income (US\$/cage) & 34.32 & -6.17 & 99.01 & 76.71 & 166.41 & -10.17 & 55.31 & \\
\hline Profitability index (\%) & 10.40 & -1.92 & 19.92 & 14.50 & 25.89 & -1.78 & 8.73 & \\
\hline Break-even point $(\mathrm{kg})$ & 192.04 & 213.25 & 258.42 & 293.71 & 309.36 & 378.62 & 375.47 & \\
\hline Productive cycle (days) & 1.45 & 2.01 & 1.41 & 1.93 & 1.49 & 1.68 & 1.80 & \\
\hline Operating income (US\$/year) & 49.70 & -12.38 & 139.53 & 148.15 & 247.92 & -17.11 & 99.44 & \\
\hline
\end{tabular}

Sale price of fish $(800 \mathrm{~g})=\mathrm{US} \$ 1.54 / \mathrm{kg}$. US $\$ 1.00=\mathrm{R} \$ 3.25$ (May 2017). 
that the most efficient farmers produce more with a smaller amount of feed during each farming cycle, considering the cost of initial investments and production costs (Sabbag and Costa, 2015). The present study demonstrated that the most efficient production model in relation to the control (production system adopted by Brazilian farmers) for $800 \mathrm{~g}$ Nile tilapia were the treatments that included a substrate. Using the highest stocking density and feed restriction of $50 \%$, the annual operating income was $57 \%$ higher than the CTRL and the profitability index was $87 \%$ higher than the CTRL. The next most efficient approach used a stocking density of $60 \mathrm{~kg} / \mathrm{m}^{3}$ with inclusion of substrates (either with or without feed restriction). At this stocking density, the treatment in which fish were fed $100 \%$ of daily ration presented annual operating income $13 \%$ higher than the CTRL and the profitability index $26 \%$ higher than the CTRL. With feed restriction of $50 \%$, the annual operating income was $7 \%$ higher than the CTRL and the profitability index was $51 \%$ higher than the CTRL.

These production models required a smaller total operating expense and resulted in increased profitability index. To select the best treatment, is important to consider that using a lower stocking density reduces the mortality risk due to diseases, poor-quality water inside the cages and reduces the environmental loading ratio and increases the system renewability, this is the proportion of renewable resources of the total inputs (Garcia et al., 2014; Garcia et al., 2013), making it safer and more sustainable. In the same way, feed restriction should be encouraged to reduce dependence of external resource, to reduce the nutrient input in the system and to allow workers to be available to perform different activities that diversify their production.

Chaibu et al. (2004) observed that the profitability index of hybrid red tilapia is highly sensitive to feed costs, market prices, income, and survival rates. Similarly, the stocking density affects the survival rate and feed conversion, which directly affects the profitability. Thus, large aquaculture businesses with intensive systems obtain higher incomes than small fish farmers, but the profitability of the small-sclae fish farmers is higher when they use a less intensive system (Lebel et al., 2013).

It is important to consider that for market niches for 500 g-tilapia, this production may become viable because allows a higher number of cycles per year. Producing up to a weight of $500 \mathrm{~g}$, the higher stocking density fed $100 \%$ of daily ration with substrates provided the best outcome, with a higher mean daily weight gain, lower feed conversion ratio, production cost per $\mathrm{kg}$ of fish produced $15 \%$ lower than the CTRL and three farming cycles per year. When fish reached $800 \mathrm{~g}$, the performance and economical results of this treatment were inferior to the CTRL group, indicating that there was a limit on the net cage's support capacity (Garcia et al., 2016).

The economic analysis for the present study used the average sales price paid by fish processing units, the most common buyers of Nile tilapia produced in net cages. However, in Brazil, smaller producers prefer to send their final product to specific markets that pay superior values over those paid by major processing units. Such sales may take place directly at big fairs like CEAGESP (São Paulo General Warehousing and Centers Company), fee fishing facilities and fish markets. Thus, the results we present reflect the worst-case market situation, and higher revenues are possible depending on the destination of the fish produced.

Considering the productivity of periphyton in substrates is regulated by resource availability (Azim et al., 2005) we encourage studies to evaluate productivity of periphyton in Brazilian reservoirs (Siqueira and Rodrigues, 2009). Moreover, we recommend studies to assess the effect of the net cage farming on periphyton productivity, since Mallasen et al. (2012) recorded high influence of the cage culture in the ecosystem over time with higher levels of nitrate and suspended material near net cages in the same reservoir of the present experiment (Nova Avanhandava, Tietê river).

\section{Conclusions}

The present study demonstrates the economical profitability of the insertion of bamboo substrates into net-cages for production of Nile tilapia. This production model offers a way for small-scale producers to increase the efficiency of the system with annual operating income up to $57 \%$ higher and the profitability index up to $87 \%$ higher than the usual system adopted by Brazilian farmers. It also enables them to devote more time to diversifying their economic activities and gives them access to the fish produced for consumption.

\section{Acknowledgments}

This study has been funded by the São Paulo Research Foundation (2013/18721-6) and grant 2014/08479-6. We thank Mr. Rodrigo Hirose (Sempre Viva fish farming) for the valuable contribution giving the location and operational support for the experiments. We thank Dr. Rogério Soares de Freitas (Instituto Agronômico de Campinas) for the technical support and Dr. Ariel Zajdband for the English and redaction review.

\section{References}

Ayroza, D.M.M.R., Garcia, F., Ayroza, L.M.S., Furlaneto, F.P.B., Ferraudo, A.S., Mercante, C.T.J., 2014. Environmental conditions, fish disease, management and economic evaluation of tilapia cages in a Brazilian hydroelectric reservoir. In: Walkefield, $\mathrm{R}$. (Ed.), Tilapia: Biology, Management Practices and Human Consumption. Nova Science Publishers, New York, pp. 119-145.

Azim, M.E., Verdegem, M.C.J., Van Dan, A.A., Beveridge, M.C.M., 2005. Periphyton: Ecology, Exploitation and Management. CABI Publishing, Cambridge, pp. 15-33.

Beveridge, M.C.M., Baird, D.J., 2000. Diet, feeding and digestive physiology. In: Beveridge, M.C.M., McAndrew, B.J. (Eds.), Tilapias: Biology and Exploitation. Kluwer Academic Publishers, Dordrecht, NED, pp. 59-87.

Chaibu, P., Ungsethaphand, T., Maneesri, S., 2004. The costs and returns of tilapia and tubtim (red tilapia) cage culture in Chiang Mai Province, Thailand. J. Fish. 57 (3), 244-250.

FAO, 2016. El estado mundial de la pesca y la acuicultura 2016. Contribución a la seguridad alimentaria y la nutrición para todos, Roma (224 pp).

Garcia, F., Romera, D.M., Gozi, K.S., Onaka, E.M., Fonseca, F.S., Schalch, S.H.C., Candeira, P.G., Guerra, L.O., Carmo, F.J., Carneiro, D.J., Martins, M.I.E., Portella, M.C., 2013. Stocking density of Nile tilapia in cages placed in a hydroelectric reservoir. Aquaculture 410-411, 51-56.

Garcia, F., Kimpara, J.M., Valenti, W.C., Ambrosio, L.A., 2014. Emergy assessment of tilapia cage farming in a hydroelectric reservoir. Ecol. Eng. 68, 72-79.

Garcia, F., Romera, D.M., Sousa, N.S., Paiva-Ramos, I., Onaka, E.M., 2016. The potential of periphyton-based cage culture of Nile tilapia in a Brazilian reservoir. Aquaculture 464, 229-235.

Huchette, S.M.H., Beveridge, M.C.M., 2003. Technical and economical evaluation of periphyton- based cage culture of tilapia (Oreochromis niloticus) in tropical freshwater cages. Aquaculture 218, 219-234.

Keshavanath, P., Gangadhar, B., Ramesh, T.J., Van Dam, A.A., Beveridge, M.C.M. Verdegem, M.C.J., 2004. Effects of bamboo substrate and supplemental feeding on growth and production of hybrid red tilapia fingerlings (Oreochromis mossambicus $\times$ Oreochromis niloticus). Aquaculture 235, 303-314.

Lebel, P., Chaibu, P., Lebel, L., 2009. Women farm fish: gender and commercial fish cage culture on the upper Ping River, Northern Thailand. Gend. Technol. Dev. 13 (2), 199-224.

Lebel, P., Whangchai, N., Chitmanat, C., Promya, J., Chaibu, P., Sriyasak, P., Lebel, L., 2013. River-based cage aquaculture of tilapia in Northern Thailand: sustainability of rearing and business practices. Nat. Resour. 4, 410-421.

Mallasen, M., Barros, H.P., Traficante, D.P., Camargo, A.L.S., 2012. Influence of a net cage tilapia culture on the water quality of the Nova Avanhandava reservoir, São Paulo State, Brazil. Acta Sci. 34 (3), 289-296.

Martin, N.B., Serra, R., Oliveira, M.D.M., Ângelo, J.A., Okawa, H., 1998. Sistema integrado de custos agropecuários - CUSTAGRI. Inf. Econ. 28 (1), 7-28.

Matsunaga, M., Bemelmans, P.F., Toledo, P.E.N., Dulley, R.D., Okawa, H., Pedroso, I.A., 1976. Metodologia de custo utilizada pelo IEA. Agric. São Paulo 23 (1), 123-139.

Norberg, J., 1999. Periphyton fouling as a marginal energy source in tropical tilapia cage farming. Aquac. Res. 30, 427-430.

Ofori, J., Abban, E., Karikari, A., Brummett, R., 2010. Production parameters and economics of small-scale tilapia cage aquaculture in the Volta Lake, Ghana. J. Appl. Aquac. 22 (4), 337-351.

Piumsombun, S., Rab, M.A.M., Dey, M., Srichantuk, N., 2005. The farming practices and economics of aquaculture in Thailand. Aquac. Econ. Manag. 9 (1-2), 265-287.

Sabbag, O.J., Costa, S.M.A.L., 2015. Eficiência técnica da produção de tilápias em Ilha Solteira, SP: uma análise não paramétrica. B. Ind. Anim. 72 (2), 155-162.

Saikia, S.K., Das, D.N., 2009. Potentiality of periphyton - based aquaculture technology in rice-fish environment. J. Sci. Res. 1 (3), 624-634.

Sakr, E.M., Shalaby, S.M., Wassef, E.A., El-Sayed, A.M., Abdel-Moneim, A.I., 2015. 
Evaluation of periphyton as a food source for Nile tilapia (Oreochromis niloticus) juveniles fed reduced protein levels in cages. J. Appl. Aquac. 27, 50-60.

Sanderson, S.L., Stebar, M.C., Ackerman, K.L., Jones, S.H., Batjakas, I.E., Kaufman, L.,

1996. Mucus entrapment of particles by suspension-feeding tilapia (Pisces:

Cichlidae). J. Exp. Biol. 199, 1743-1756.

Setboonsarng, S., Edwards, P., 1998. An assessment of alternative strategies for the integration of pond aquaculture into the small-scale farming system of Northeast Thailand. Agric. Econ. Manag. 2 (3), 151-162.

Siqueira, N., Rodrigues, L., 2009. Biomassa perifítica em tanques-rede de criação de

tilápia do nilo - Oreochromis niloticus (Linneau, 1758). Bol. Inst. Pesca 35 (2),

181-190. 